\title{
Phenazine antibiotics produced by fluorescent pseudomonads contribute to natural soil suppressiveness to Fusarium wilt
}

\author{
Sylvie Mazurier ${ }^{1}$, Thérèse Corberand ${ }^{1}$, Philippe Lemanceau ${ }^{1}$ and Jos M Raaijmakers ${ }^{2}$ \\ ${ }^{1}$ INRA, Université de Bourgogne, UMR 1229 'Microbiologie des Sols et de l'Environnement,' Dijon cedex, \\ France and ${ }^{2}$ Laboratory of Phytopathology, section 'Molecular Ecology and Biological Control,' Wageningen \\ University, Wageningen, The Netherlands
}

\begin{abstract}
Natural disease-suppressive soils provide an untapped resource for the discovery of novel beneficial microorganisms and traits. For most suppressive soils, however, the consortia of microorganisms and mechanisms involved in pathogen control are unknown. To date, soil suppressiveness to Fusarium wilt disease has been ascribed to carbon and iron competition between pathogenic Fusarium oxysporum and resident non-pathogenic $F$. oxysporum and fluorescent pseudomonads. In this study, the role of bacterial antibiosis in Fusarium wilt suppressiveness was assessed by comparing the densities, diversity and activity of fluorescent Pseudomonas species producing 2,4-diacetylphloroglucinol (DAPG) $\left(p h / D^{+}\right)$or phenazine $\left(p h z C^{+}\right)$ antibiotics. The frequencies of $p h / D^{+}$populations were similar in the suppressive and conducive soils but their genotypic diversity differed significantly. However, ph/D genotypes from the two soils were equally effective in suppressing Fusarium wilt, either alone or in combination with nonpathogenic $F$. oxysporum strain Fo47. A mutant deficient in DAPG production provided a similar level of control as its parental strain, suggesting that this antibiotic does not play a major role. In contrast, $p h z \mathrm{C}^{+}$pseudomonads were only detected in the suppressive soil. Representative $p h z \mathrm{C}$ isolates of five distinct genotypes did not suppress Fusarium wilt on their own, but acted synergistically in combination with strain Fo47. This increased level of disease suppression was ascribed to phenazine production as the phenazine-deficient mutant was not effective. These results suggest, for the first time, that redox-active phenazines produced by fluorescent pseudomonads contribute to the natural soil suppressiveness to Fusarium wilt disease and may act in synergy with carbon competition by resident non-pathogenic $F$. oxysporum.
\end{abstract}

The ISME Journal (2009) 3, 977-991; doi:10.1038/ismej.2009.33; published online 16 April 2009

Subject Category: microbial ecology and functional diversity of natural habitats

Keywords: disease-suppressive soil; fluorescent pseudomonads; Fusarium wilt; phenazine antibiotics

\section{Introduction}

The natural selection has resulted in numerous examples of genetic resistance in plants to aboveground pathogens, but curiously enough not to many below-ground pathogens. Cook et al. (1995) postulated that plants have developed an entirely different strategy to defend themselves against soilborne pathogens. This strategy involves the ability of plants to selectively stimulate and support

Correspondence: P Lemanceau, UMR Microbiologie du Sol et de l'Environnement, INRA/Université de Bourgogne, CMSE, BP 86510, Dijon cedex 21065, France.

E-mail: lemanceau@dijon.inra.fr

Received 4 November 2008; revised 17 February 2009; accepted 23 February 2009; published online 16 April 2009 populations of soil and rhizosphere microorganisms that are antagonistic to their pathogens. Natural disease-suppressive soils are the best examples in which the activities of specific soil and rhizosphere microorganisms keep susceptible plants almost free of infection in spite of ample exposure to virulent inoculum of soil-borne pathogens. Natural diseasesuppressive soils occur worldwide and provide an enormous resource for the discovery of novel beneficial microorganisms and traits (Weller et al., 2002). For most of the disease-suppressive soils, however, the consortia of microorganisms and mechanisms involved in pathogen control have not yet been identified.

The disease-suppressive soils have been classified as 'long-standing suppressive soils' and 'induced suppressive soils' according to the longevity of 
disease suppression (Hornby, 1979; Weller et al., 2002). Long-standing suppressiveness is a biological condition naturally associated with the soil, its origin is not known and it appears to survive in the absence of plants. In contrast, induced suppressiveness is initiated and sustained by crop monoculture in the presence of the pathogen (Weller et al., 2002). Soils suppressive to take-all disease of wheat and barley, caused by the fungal pathogen Gaeumannomyces graminis var. tritici, are referred to as take-all decline soils and are well-known examples of induced suppressiveness. The Fusarium-wilt suppressive soils from Châteaurenard (France) and Salinas Valley (CA, USA) are among the best examples of long-standing suppressive soils.

Fusarium wilts are caused by plant pathogenic Fusarium oxysporum leading to significant yield losses in many crops worldwide. Fusarium-wilt suppressive soils substantially limit the disease incidence or severity, but are not suppressive to diseases caused by non-vascular Fusarium species or other soil-borne pathogens (Alabouvette, 1986). The microbiological nature of the disease suppression in Fusarium-wilt suppressive soils was unequivocally shown by a range of approaches, including treatments with moist heat, methylbromide or $\gamma$-irradiation leading to loss of soil suppressiveness, and by experiments in which suppressiveness was transferred to wilt-conducive soils by mixing small amounts $(0.1-10 \% \mathrm{wt} / \mathrm{wt})$ of the suppressive soil into the conducive soil (Scher and Baker, 1980; Alabouvette, 1986; Weller et al., 2002). Fusariumwilt suppressive soils maintain their activity when brought into the greenhouse or laboratory, which greatly facilitates the identification of the microorganisms, mechanisms and genes involved in disease suppressiveness.

Among the bacterial and fungal genera proposed to contribute to Fusarium wilt suppressiveness are Alcaligenes (Yuen and Schroth, 1986), Trichoderma (Sivan and Chet, 1989), Actinomycetes (Amir and Amir, 1989), Pseudomonas (Kloepper et al., 1980; Scher and Baker, 1982; Lemanceau and Alabouvette, 1993) and non-pathogenic F. oxysporum (Alabouvette, 1986; Larkin et al., 1996). Detailed studies on Fusarium-wilt suppressive soils from Châteaurenard (France) and Salinas Valley showed that the suppressiveness was attributed, in particular, to the activity of non-pathogenic $F$. oxysporum and fluorescent pseudomonads (Scher and Baker, 1982; Alabouvette, 1990; Lemanceau and Alabouvette, 1991; Duijff et al., 1999). For the non-pathogenic F. oxysporum, competition for carbon and induced systemic resistance were the main modes of action proposed so far (Steinberg et al., 2007). For the fluorescent pseudomonads, siderophore-mediated competition for iron was shown to be a major mechanism in the control of Fusarium wilts (Scher and Baker, 1982; Lemanceau et al., 1992). Particularly interesting from these studies was that the association between non-pathogenic $F$. oxysporum and fluorescent pseudomonads provided enhanced disease suppression (Lemanceau et al., 1993). Work by Duijff et al. (1999) supported and extended the earlier observations that disease suppression by the non-pathogenic $F$. oxysporum is related to reductions in both population density and metabolic activity of the pathogen on the root surface, and that competition for iron contributes to the suppression by Pseudomonas and enhances the biological activity of the non-pathogenic $F$. oxysporum.

In contrast to other disease-suppressive soils, the role of antibiosis in Fusarium-wilt suppressive soils has not been studied to date, in spite of the fact that several antibiotic compounds produced by antagonistic bacteria have shown growth-inhibitory activity against pathogenic $F$. oxysporum. For example, phenazine antibiotics were shown to play a key role in the biocontrol activity of several Pseudomonas species against $F$. oxysporum on diverse crops (Anjaiah et al., 1998; Chin-A-Woeng et al., 1998, 2000). Also the antibiotic 2,4-diacetylphloroglucinol (DAPG) has substantial activity against pathogenic F. oxysporum (Schouten et al., 2004), and populations of DAPG-producing pseudomonads were highly enriched in a soil naturally suppressive to Fusarium wilt of peas (Landa et al., 2002). Following similar molecular-based approaches used to unravel the role of antibiosis in take-all decline soils (Raaijmakers et al., 1997; Raaijmakers and Weller, 1998; McSpadden-Gardener et al., 2000; Weller et al., 2002; Souza et al., 2003a) and in soils suppressive to black root rot of tobacco (Wang et al., 2001; Ramette et al., 2003, 2006; Frapolli et al., 2007), the objectives of this study were to determine the frequency, diversity and biocontrol activity of DAPG $\left(p h l \mathrm{D}^{+}\right)$- and phenazine $\left(p h z \mathrm{C}^{+}\right)$-producing pseudomonads in the Fusarium-wilt suppressive soil from Châteaurenard (France) in comparison with the conducive soil of Carquefou (France). The results showed that densities of $p h l \mathrm{D}^{+}$populations were not significantly different between the two soils but that their genotypic diversity differed significantly. However, the suppressive ability of isolates representative of the $p h l \mathrm{D}^{+}$diversity found in the two soils was similar. In contrast, $p h z \mathrm{C}^{+}$ populations were only detected in the Fusariumwilt suppressive soil and isolates representative of their diversity significantly improved the biocontrol activity achieved by non-pathogenic $F$. oxysporum. These results indicate, for the first time, that phenazine-producing pseudomonads are enriched in the Fusarium-wilt suppressive soil from Châteaurenard and, when reintroduced in association with non-pathogenic $F$. oxysporum, significantly enhance the soil suppressiveness to Fusarium wilt. Bioassays with a phenazine-deficient mutant showed that phenazine production is involved in this augmentation of disease suppression. Collectively, these results suggest a role of redoxactive phenazine antibiotics in the natural soil suppressiveness to Fusarium wilts. A model is 
presented depicting the versatility of the mechanisms and the complex interplay between consortia of antagonistic microorganisms in Fusarium-wilt suppressive soil.

\section{Materials and methods}

Microorganisms and soils used

Characteristics of the Pseudomonas reference strains are given in Table 1. All Pseudomonas strains were cultivated on KMB agar (King et al., 1954 ) at $25^{\circ} \mathrm{C}$. The flax pathogen Fusarium oxysporum f. sp. lini Foln3 and the non-pathogenic strain F. oxysporum Fo47 were obtained from the MIAE Culture Collection (INRA, Dijon, France), and grown on Difco potato dextrose agar (PDA; Difco Laboratories, Detroit, MI, USA) at $24^{\circ} \mathrm{C}$. Soil naturally suppressive to Fusarium wilt was obtained from Châteaurenard, and the conducive soil from Carquefou. The main characteristics of these soils have been described earlier (Lemanceau et al., 1988). Briefly, the soils from Châteaurenard and Carquefou are calcic silt-clay and sandy-loam soils, respectively. The calcium carbonate content and $\mathrm{pH}$ of the Châteaurenard soil $\left(37.4 \% \mathrm{CaCO}_{3}, \mathrm{pH}\right.$ 7.9) are much higher than those of the Carquefou soil $(8.4 \%$ $\mathrm{CaCO}_{3}$, pH 5.3). These two characteristics account for the very low concentration of extractable iron of the Châteaurenard soil (18.8 p.p.m.), 15 times lower than that of the Carquefou soil (279.9 p.p.m.), even though both soils share a comparable concentration of total iron, that is, $11 \%$ and $9 \%$ for the Châteaurenard and Carquefou soils, respectively. Biocontrol assays were performed in a soil collected from a fallow field in Dijon (France) for which the proper- ties were described in Latour et al. (1996). The phenazine-producing strain $P$. fluorescens $2-79$ and its phenazine-deficient mutant 2-79Z were kindly provided by D Mavrodi and L Thomashow (Washington state University, Pullman, WA, USA) (Khan et al., 2005). DAPG-deficient mutant 17-8D was obtained by plasposon mutagenesis of strain Phl60rif, and its inability to produce DAPG was confirmed by RP-HPLC analysis (data not shown). The deficiency in phenazine production by mutant 2-79Z was previously demonstrated by Khan et al. (2005).

Frequency of indigenous $\mathrm{phl} D^{+}$and $\mathrm{phz} C^{+}$ pseudomonads in soil and rhizosphere

Fluorescent pseudomonads harboring the phID $\left(p h l \mathrm{D}^{+}\right)$or $p h z \mathrm{C}\left(p h z \mathrm{C}^{+}\right)$genes were isolated and enumerated in bulk soil and in the rhizosphere of flax and tomato according to the methods described by Raaijmakers et al. (1997) and Souza et al. (2003a). Briefly, surface-sterilized seeds of flax (Linum usitatissimum L. cv. Opaline) and tomato (Lycopersicon esculentum Mill. cv. H63-5) were sown in the wilt suppressive and conducive soils, and the plants were grown for 4 weeks under controlled conditions (12:12 h light/dark photoperiod under photosynthetic active radiation of $215 \mu \mathrm{E} \mathrm{m}^{-2} \mathrm{~s}^{-1}, 25: 22{ }^{\circ} \mathrm{C}$ light/dark thermoperiod). For each of the two soils, five pots ( $3 \mathrm{l}$ ) were used for flax and five for tomato; each pot contained $2 \mathrm{l}$ of soil and five seeds. One series of five pots was kept uncultivated (bulk soil). Rhizosphere and bulk soil samples were obtained as described earlier (Raaijmakers et al., 1997) and dilution plated onto KMB agar supplemented

Table 1 Reference strains of 2,4-diacetylphloroglucinol (DAPG) and phenazine-producing Pseudomonas spp. used in this study

\begin{tabular}{|c|c|c|c|}
\hline Strain & Origin & Species & Source or reference \\
\hline \multicolumn{4}{|c|}{ DAPG producer } \\
\hline PWB233 & Wheat, The Netherlands & Pseudomonas sp. & Bergsma-Vlami et al. (2005) \\
\hline PWB532 & Wheat, The Netherlands & Pseudomonas sp. & Bergsma-Vlami et al. (2005) \\
\hline PPB2310 & Potato, The Netherlands & Pseudomonas sp. & Bergsma-Vlami et al. (2005) \\
\hline PPB3512 & Potato, The Netherlands & Pseudomonas sp. & Bergsma-Vlami et al. (2005) \\
\hline PSB211 & Sugar beet, The Netherlands & Pseudomonas sp. & Bergsma-Vlami et al. (2005) \\
\hline PSC2218 & Sugar beet, The Netherlands & Pseudomonas sp. & Bergsma-Vlami et al. (2005) \\
\hline PSC415 & Sugar beet, The Netherlands & Pseudomonas sp. & Bergsma-Vlami et al. (2005) \\
\hline F113 & Sugar beet, Ireland & P. fluorescens & Shanahan et al. (1992) \\
\hline Q2-87 & Take-all suppressive soil, wheat, USA & P. fluorescens & Vincent et al. (1991) \\
\hline Q8r1-96 & Take-all suppressive soil, wheat, USA & P. fluorescens & Raaijmakers and Weller (1998) \\
\hline СНAO & Black root rot suppressive soil, tobacco, Switzerland & P. fluorescens & Stutz et al. (1986) \\
\hline Pf-5 & Cotton, USA & P. fluorescens & Howell and Stipanovic (1979) \\
\hline Phl60rif & Take-all suppressive soil, wheat, The Netherlands & Pseudomonas sp. & Souza et al. (2003b) \\
\hline $17-8 \mathrm{D}$ & DAPG-deficient mutant of Phl60rif & Pseudomonas sp. & Unpublished data \\
\hline \multicolumn{4}{|c|}{ Phenazine producer } \\
\hline $2-79$ & Take-all suppressive soil, wheat, USA & P. fluorescens & Weller and Cook (1983) \\
\hline $2-79 Z$ & Phenazine-deficient mutant of 2-79; phzD::lacZ & P. fluorescens & Khan et al. (2005) \\
\hline PGS12 & Corn, Belgium & P. aureofaciens & Georgakopoulos et al. (1994) \\
\hline PCL1391 & Tomato, Spain & P. chlororaphis & Chin-A-Woeng et al. (1998) \\
\hline $30-84$ & Take all suppressive soil, wheat, USA & P. aureofaciens & Pierson and Thomashow (1992) \\
\hline PAO1 & Burned patient, Australia & P. aeruginosa & Holloway (1955) \\
\hline
\end{tabular}


with cycloheximide $\left(100 \mathrm{mg} \mathrm{l}^{-1}\right)$, chloroamphenicol $\left(13 \mathrm{mgl}^{-1}\right.$ ) and ampicillin $\left(40 \mathrm{mgl}^{-1}\right.$ ) (Simon and Ridge, 1974). After $48 \mathrm{~h}$ of incubation at $25^{\circ} \mathrm{C}$, colonies were counted and fluorescent pseudomonads were differentiated from non-fluorescent colonies under UV light (wavelength, $365 \mathrm{~nm}$ ). The numbers of fluorescent pseudomonads that harbored the phID gene or the $p h z \mathrm{C}$ gene were determined by colony hybridization followed by PCR analysis as described earlier (Raaijmakers et al., 1997; Souza et al., 2003a). The phID and phzC probes were obtained by labeling of a 629-bp phID fragment obtained from the reference strain $P$. fluorescens Phl60rif, and of a 522-bp phzC fragment from the reference strain $P$. fluorescens 2-79. Digoxigenin labeling of the DNA probes was carried out by random priming using the DIG DNA labeling kit (Roche, Meylan, France). Primers B2BF and BPR4 (McSpadden-Gardener et al., 2001) were used to amplify the 629-bp phID fragment and primers PHZJR1 5'-CAGGGCCG(G/C)(A/G)(C/T)ATTTCTCG GTTCT-3' and PHZJR2 5'-GCGCGGGTCGCACAGG CTTTTGTA-3' for the 522-bp phzC fragment. The hybridized probes were immunodetected with antidigoxigenin-alkaline phosphatase-Fab fragments and visualized with the colorometric substrates nitroblue tetrazolium salt and 5-bromo-4-chloro-3indolylphosphate, as described by the supplier (Roche). The colonies that were positive in hybridization were purified and subjected to PCR analysis with primers specific for phlD or phzC. For statistical analysis, population densities were $\log _{10}$ transformed and significant differences were assessed by analysis of variance followed by StudentNewman-Keuls tests (SAS Institute Inc., Cary, NC, USA).

Genetic diversity of $\mathrm{phl} D^{+}$and $\mathrm{phz} C^{+}$pseudomonads Restriction-fragment length polymorphism (RFLP) analysis of the 629-bp phID PCR product amplified from the indigenous isolates and reference strains was performed using the restriction enzymes HaeIII, MspI and TaqI (McSpadden-Gardener et al., 2001). For RFLP analysis of the 522-bp phzC fragments, the restriction enzymes Fnu4HI, NciI, NlaIV, NdeII, DdeI and Cfr13I were used. Restriction patterns were determined by electrophoresis at $80 \mathrm{~V}$ in TAE buffer with 3.5\% (w/v) Metaphor agarose (Tebu, Le Perray-en-Yvelines, France). A similarity matrix was calculated using the pair wise Jaccard similarity coefficient (Jaccard, 1908). Cluster analysis was performed by the unweighted pair group method using arithmetic averages allowing the delineation of phlD and phzC genotypes. As phID genotypes were earlier shown to correlate almost perfectly with those defined by BOX-PCR (Mavrodi et al., 2001; McSpadden-Gardener et al., 2001; Landa et al., 2002, 2006, Weller et al., 2002; De La Fuente et al., 2006), BOX-PCR was only performed for $p h z \mathrm{C}^{+}$ isolates. The protocol used was described by
Rademaker et al. (1997), except for the Taq Polymerase. Four units of Taq DNA polymerase (QBIOgene, Illkirsch, France) were used in each $25 \mu \mathrm{l}$ BOX-PCR. BOX-PCR fragments were separated overnight at $40 \mathrm{~V}$ in a $1.5 \%(\mathrm{w} / \mathrm{v})$ Seakem LE agarose gel (Tebu) in TAE buffer. For each BOX-PCR fingerprint, a binary data matrix with 79 bands being either present (1) or absent (0) was established. A similarity matrix was calculated using the pair wise Pearson product-moment correlation coefficient. Cluster analysis was performed by unweighted pair group method using arithmetic averages. Isolates presenting Pearson product-moment correlation coefficients $\geqslant 0.75$ were assigned to a BOX-PCR genotype named with a same letter (A-J) and, within these genotypes, those having a correlation coefficient equal to 1 were assigned a BOX-PCR genotype named with the same number (that is, A1). Next to RFLP and BOX-PCR analyses, phID and phzC PCR fragments were cloned (pGEMT Easy Vector System II, Promega, Charbonnières, France) and sequenced (Genome Express, Meylan, France). BLAST analyses and CLUSTAL W (Thompson et al., 1994) were applied for multiple sequence alignments. Phylogenies were determined by neighbor-joining method (Saitou and Nei, 1987) using the Kimura '2-parameters' correction (Kimura, 1980) with the pair wise gap removal option. To estimate tree node validity, results of 1000 bootstrapped data sets were determined.

\section{Biocontrol efficacy of $\mathrm{phl} D^{+}$and $\mathrm{phz} C^{+}$ pseudomonads}

The phlD ${ }^{+}$and $p h z \mathrm{C}^{+}$Pseudomonas isolates were grown on $\mathrm{KMB}$ agar plates for $48 \mathrm{~h}$ at $25^{\circ} \mathrm{C}$ and cells were harvested and washed once in sterile distilled water. The cell density was determined spectrophotometrically at $600 \mathrm{~nm}$ and adjusted to $10^{7} \mathrm{CFU} \mathrm{g}^{-1}$ of fresh soil. Inoculums of the pathogenic $F$. oxysporum f. sp. lini Foln3 and nonpathogenic $F$. oxysporum Fo47 were prepared as described earlier (Lemanceau and Alabouvette, 1991). The fungal suspensions were adjusted to $10^{5}$ conidiag $^{-1}$ of soil fresh weight for $F$. oxysporum Fo47, and $10^{3}$ conidiag $^{-1}$ of soil fresh weight for F. oxysporum f. sp. lini Foln3. Flax plants were grown in environment-controlled growth chamber (15:9 h light/dark photoperiod under photosynthetic active radiation of $215 \mu \mathrm{E} \mathrm{m}^{-2} \mathrm{~s}^{-1}, 26: 20^{\circ} \mathrm{C}$ light/dark thermoperiod). The relative humidity in the growth chamber was maintained at $60 \%$ during the night and $80 \%$ during the day. Each flax plant was grown individually in a plastic tray cell filled with $50 \mathrm{ml}$ of autoclaved (three successive treatments at $100{ }^{\circ} \mathrm{C}$ for $1 \mathrm{~h}$, each one separated by $24 \mathrm{~h}$ ) Dijon soil placed on top of a draining layer of extruded clay beads. Surface sterilized flax seeds were sown in the filled plastic tray cells and inoculated with conidial and bacterial suspensions. Each treatment consisted of three replicate trays of 16 plants arranged in a randomized complete block experimental design. 
Plants showing the typical symptoms of Fusarium wilt were recorded twice a week for a period of 6 weeks, and cumulated numbers of diseased plants were used to determine the area under the disease progress curve (AUDPC) according to the methods described by Steinberg et al. (2004). Differences in disease severity between treatments were determined by analysis of variance followed by Fisher's PLSD-test (SAS Institute Inc.).

\section{Results}

Frequency of antibiotic-producing pseudomonads in disease suppressive and conducive soils

Population densities of fluorescent pseudomonads harboring the biosynthesis gene phID for DAPG or $p h z \mathrm{C}$ for phenazine production were assessed in bulk soils and in the rhizosphere of tomato and flax seedlings grown in the Fusarium wilt suppressive (Châteaurenard) and conducive (Carquefou) soils. phID ${ }^{+}$pseudomonads were not detected in the two bulk soils (detection limit was $3.3 \times 10^{1} \mathrm{CFU} \mathrm{g}^{-1}$ soil fresh weight). In contrast, $p h z \mathrm{C}^{+}$pseudomonads were detected in the wilt-suppressive bulk soil at an average density of $3.9 \times 10^{3} \mathrm{CFUg}^{-1}$ soil fresh weight, representing $1.3 \%$ of the total population of fluorescent pseudomonads. phz $\mathrm{C}^{+}$pseudomonads were not detectable in the conducive soil (data not shown). When flax or tomato seedlings were cultivated in these soils, phlD ${ }^{+}$pseudomonads were detected in the rhizosphere of both crops at densities ranging from $4.1 \times 10^{3}$ to $4.7 \times 10^{5} \mathrm{CFU} \mathrm{g}^{-1}$ root fresh weight (Table 2), representing on an average $3.7-26.1 \%$ of the total population of culturable fluorescent pseudomonads. Owing to variations among replicates, no significant differences in the population densities of $p h l \mathrm{D}^{+}$pseudomonads were found between the wilt suppressive and conducive soils, either in flax or tomato rhizospheres. phz $\mathrm{C}^{+}$ pseudomonads were detected in the rhizosphere of flax and tomato grown in the wilt-suppressive soil at average densities of $1.1 \times 10^{3} \mathrm{CFUg}^{-1}$ and $1.3 \times 10^{4} \mathrm{CFUg}^{-1}$ root, respectively, representing on an average $0.6-13.9 \%$ of the total rhizosphere population of culturable pseudomonads. In the rhizosphere of flax and tomato plants grown in the wilt-conducive soil, $p h z \mathrm{C}^{+}$pseudomonads were not detected (Table 2).

Diversity of $\operatorname{phl} D^{+}$pseudomonads

For a total of $95 \mathrm{phl \textrm {D } ^ { + }}$ isolates from the suppressive and conducive soils, and $13 \mathrm{phlD}^{+}$reference strains, phID-RFLP analysis was performed to assess the genotypic diversity (Figure 1). The 95 indigenous isolates comprised 24 from Châteaurenard tomato rhizosphere (designated ChPhlTR), 18 from Châteaurenard flax rhizosphere (designated ChPhlLR), 27 from Carquefou tomato rhizosphere (designated CaPhlTR) and 26 from Carquefou flax rhizosphere (designated CaPhlLR). Among the indigenous $p h l \mathrm{D}^{+}$isolates, seven distinct $p h l \mathrm{D}-\mathrm{RFLP}$ genotypes could be distinguished: (i) three phlDRFLP genotypes corresponded to the known genotypes F, M and O (De La Fuente et al., 2006), and (ii) four genotypes, designated $\alpha, \beta, \gamma$ and $\delta$, were not described earlier (Figure 1). The $42 \mathrm{phlD}^{+}$isolates obtained from the rhizosphere of tomato and flax grown in the Châteaurenard wilt suppressive soil were classified as the M-genotype (34 isolates) or the F-genotype (8 isolates). Most of the $53 \mathrm{ph}^{+} \mathrm{D}^{+}$ isolates obtained from the rhizosphere of tomato and flax grown in the Carquefou conducive soil were different from the Châteaurenard isolates and belonged to six phID-RFLP genotypes, including $\mathrm{F}$ (6 isolates), $\mathrm{O}$ (4 isolates), $\alpha$ ( 1 isolate), $\beta$ (6 isolates), $\gamma$ (26 isolates) and $\delta$ (10 isolates) (Figure 1). Subsequent sequencing of the 629-bp phlD gene fragment of representative isolates of each of the phID-RFLP groups followed by phylogenetic analysis strongly supported the classification based on phID-RFLP analysis and confirmed that the phlD ${ }^{+}$ isolates belonging to the new RFLP groups $\alpha, \beta, \gamma$

Table 2 Densities of total, phlD ${ }^{+}$and $p h z \mathrm{C}^{+}$populations of culturable fluorescent pseudomonads in the rhizosphere of flax and tomato plants grown in the Fusarium-wilt suppressive soil (Châteaurenard, France) or in the wilt-conducive soil (Carquefou, France)

\begin{tabular}{|c|c|c|c|}
\hline & Total population $C F U g^{-1}$ root & phl $D^{+}$population $C F U g^{-1}$ root & phz $C^{+}$population $C F U g^{-1}$ root \\
\hline \multicolumn{4}{|l|}{ Flax } \\
\hline Suppressive soil & $\begin{array}{c}9.4 \times 10^{4} \mathrm{~b} \\
\text { (s.d. } 8.9 \times 10^{4} \text { ) }\end{array}$ & $\begin{array}{c}4.1 \times 10^{3} \mathrm{x} \\
\text { (s.d. } 9.2 \times 10^{3} \text { ) }\end{array}$ & $\begin{array}{c}1.1 \times 10^{3} \mathrm{z} \\
\text { (s.d. } 2.4 \times 10^{3} \text { ) }\end{array}$ \\
\hline Conducive soil & $\begin{array}{c}2.3 \times 10^{6} \mathrm{a} \\
\text { (s.d. } 2.6 \times 10^{6} \text { ) }\end{array}$ & $\begin{array}{c}4.7 \times 10^{5} \mathrm{x} \\
\text { (s.d. } 5.4 \times 10^{5} \text { ) }\end{array}$ & $\mathrm{ND}^{\mathrm{a}}$ \\
\hline \multicolumn{4}{|l|}{ Tomato } \\
\hline Suppressive soil & $\begin{array}{c}1.3 \times 10^{5} \mathrm{ab} \\
\left(\text { s.d. } 1.5 \times 10^{5}\right)\end{array}$ & $\begin{array}{c}2.1 \times 10^{4} \mathrm{x} \\
\left(\text { s.d. } 4.3 \times 10^{4}\right)\end{array}$ & $\begin{array}{c}1.3 \times 10^{4} \mathrm{y} \\
\text { (s.d. } 1.2 \times 10^{4} \text { ) }\end{array}$ \\
\hline Conducive soil & $\begin{array}{c}1.8 \times 10^{5} \mathrm{ab} \\
\left.\text { (s.d. } 2.3 \times 10^{5}\right)\end{array}$ & $\begin{array}{c}2.1 \times 10^{4} \mathrm{x} \\
\left(\text { s.d. } 3.6 \times 10^{4}\right)\end{array}$ & $\mathrm{ND}^{\mathrm{a}}$ \\
\hline
\end{tabular}

${ }^{a} \mathrm{ND}$, below the detection limit of $3.3 \times 10^{2} \mathrm{CFU} \mathrm{g}^{-1}$ root.

Population densities are expressed as CFUg ${ }^{-1}$ root fresh weight. Mean values of five replicates are given and s.d. (in parentheses) refers to the s.d. of the mean. Within a given column, means with the same letter are not significantly different $(P \leqslant 0.05)$ according to Student-Newman-Keuls test. 


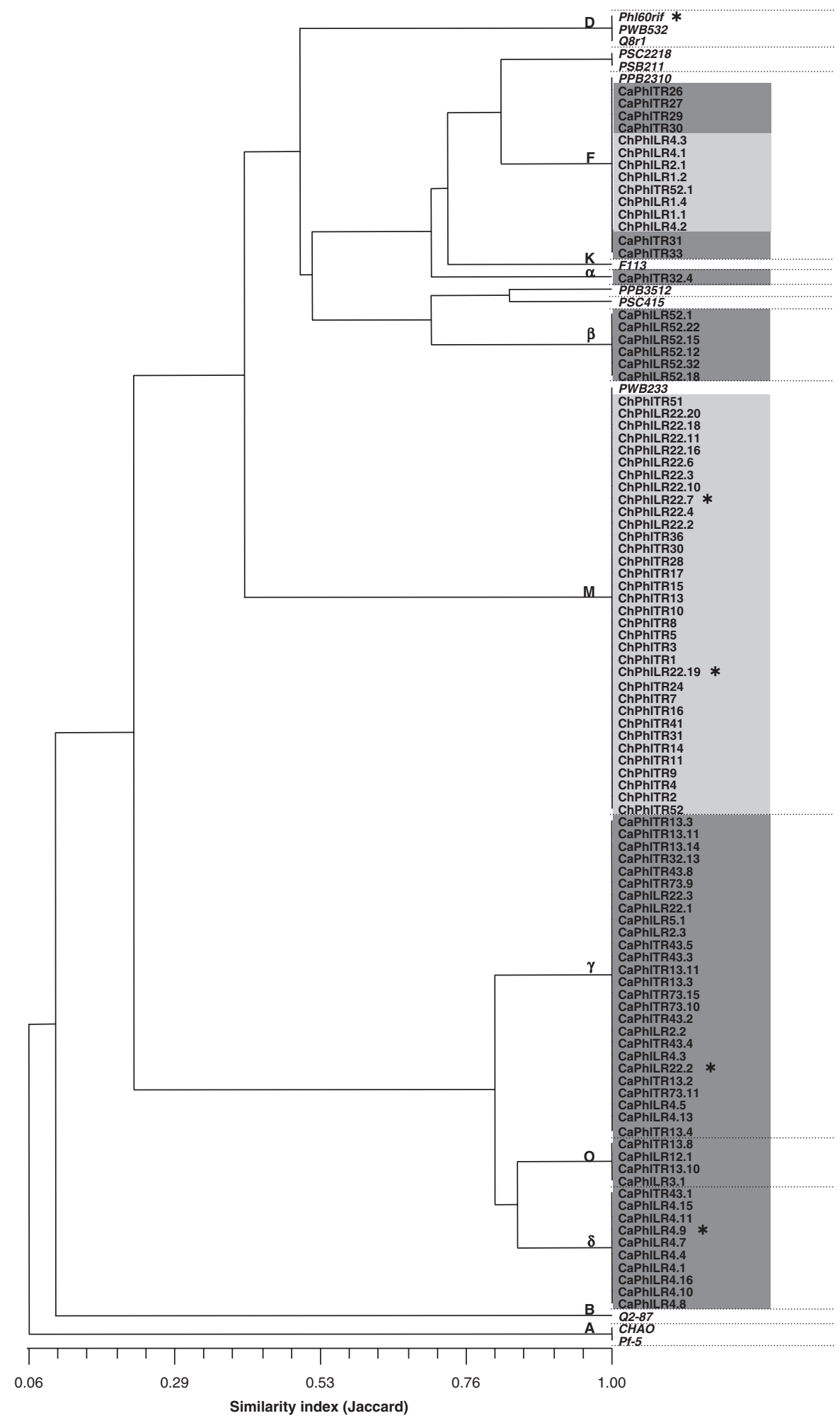

Figure 1 Diversity and phylogeny of phlD ${ }^{+}$fluorescent Pseudomonas isolates obtained from the Fusarium-wilt suppressive soil of Châteaurenard (indicated in light gray) and the conducive soil of Carquefou (indicated in dark gray). The pair wise coefficients of similarity were clustered with the unweighted pair group method using arithmetic averages algorithm of NTSYS-pc 2.02. PhID ${ }^{+}$ reference strains are presented in italics. The phID genotype designations A, B, D, F, K, M and O are based on work of De La Fuente et al. (2006), whereas the novel phID genotypes $\alpha, \beta, \gamma$ and $\delta$ were identified in this study. Isolates tested in this study for their efficacy to suppress Fusarium wilt of flax are indicated with an asterisk. 
and $\delta$ were indeed different from the other isolates and from the phlD ${ }^{+}$reference strains described so far (Supplementary Figure S1). RP-HPLC analysis confirmed that each of the isolates, for which the phlD gene was sequenced, produced DAPG in vitro (data not shown). These results indicate that, in spite of similar rhizosphere population densities in the suppressive and conducive soils (Table 2), most of the $p h l \mathrm{D}^{+}$isolates from the wilt-suppressive soil were genotypically different from those isolated from the conducive soil (Figure 1).

\section{Diversity of $\mathrm{phz} C^{+}$pseudomonads}

Twenty-nine $p h z \mathrm{C}^{+}$isolates were selected from the Châteaurenard suppressive bulk soil and from the rhizosphere of flax and tomato seedlings grown in this soil, ten from bulk soil (ChPhzS), three from flax rhizosphere (ChPhzLR) and 16 from tomato rhizosphere (ChPhzTR). Diversity was assessed by phzC-RFLP analysis, and by BOX-PCR and sequence analyses. Among the indigenous $p h z \mathrm{C}^{+}$isolates, five distinct phzC-RFLP genotypes (I, II, III, IV and VII) could be distinguished, two of which clustered with the phenazine-producing reference strains P. chlororaphis PCL1391 (genotype II) and $P$. fluorescens 2-79 (genotype VII) (Figure 2). BOX-PCR analysis revealed 11 distinct genotypes, designated A1, A2, B1, B2, C1, F1-F3, F5, G1 and $\mathrm{H} 1$, providing an additional level of discrimination between the isolates within each phzC-RFLP group (Figure 2). For example, the three $p h z \mathrm{C}^{+}$ isolates belonging to RFLP group VII could be discriminated in three BOX-PCR genotypes (G1, $\mathrm{H} 1$ and I1). Sequence and phylogenetic analyses of the phzC genes from 10 indigenous isolates, five reference strains, and $12 \mathrm{phzC}$ sequences available in genomic databases showed that seven indigenous isolates clustered with the reference strains PGS12 and 30-84 (Supplementary Figure S2). Consistent with the classification based on phzC-RFLP and BOX-PCR analyses, isolates ChPhzTR44 and ChPhzS26 were most similar to reference strain PCL1391, and isolate ChPhzLR107 to reference strain 2-79 (Supplementary Figure S2). RP-HPLC analysis confirmed that each of the

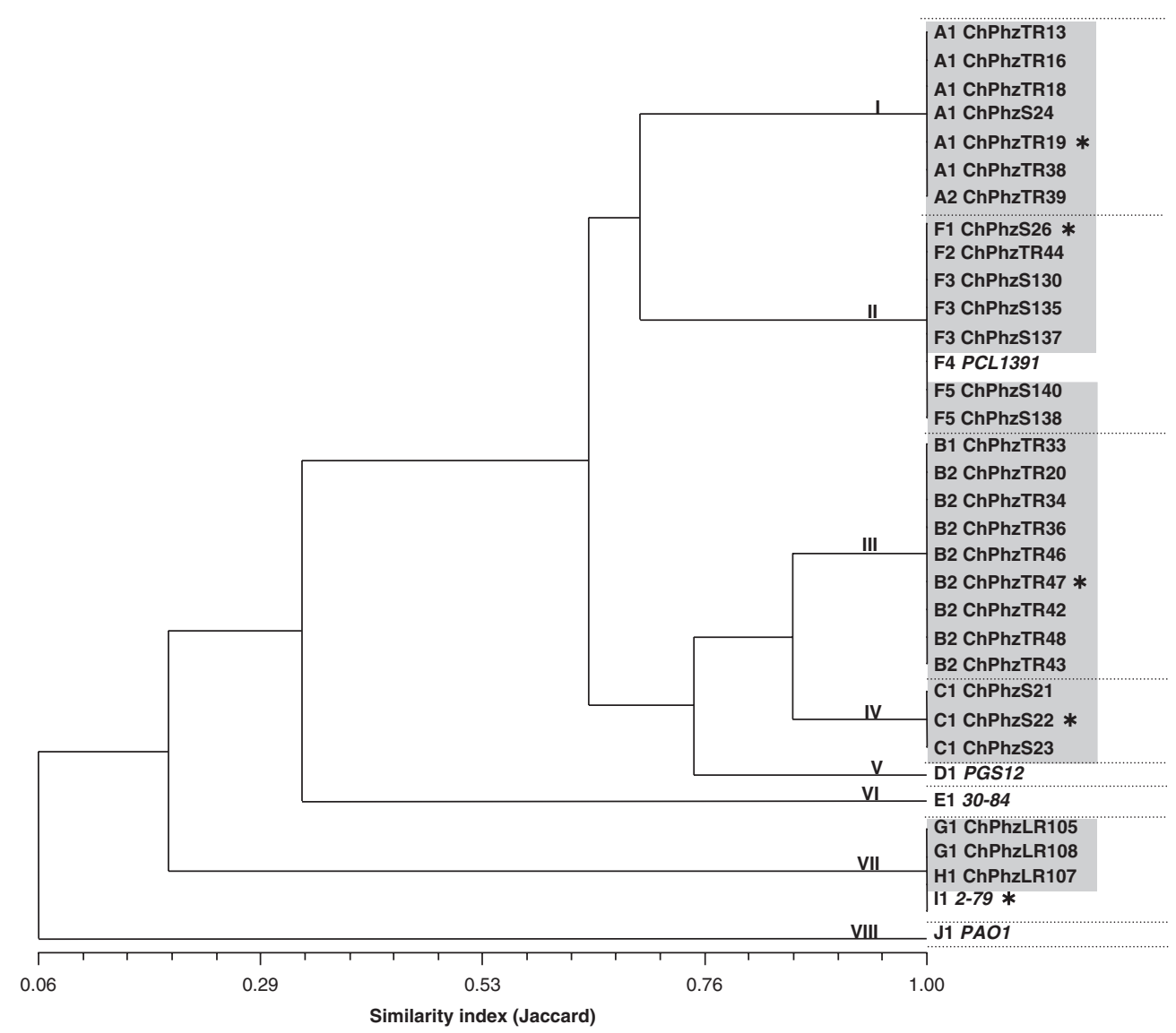

Figure 2 Diversity and phylogeny of $\mathrm{phzC}^{+}$fluorescent Pseudomonas isolates obtained from the Fusarium-wilt suppressive soil of Châteaurenard (highlighted in light gray). The pair wise coefficients of similarity were clustered with the unweighted pair group method using arithmetic averages algorithm of NTSYS-pc 2.02. PhzC reference strains are indicated in italics. For the phzC ${ }^{+}$Pseudomonas isolates with RFLP-genotypes I to VIII, the corresponding BOX-PCR genotypes (A1 to J1) are indicated in bold in front of the strains name. Isolates tested in this study for their efficacy to suppress Fusarium wilt of flax are indicated with an asterisk. 
isolates for which the phzC gene was sequenced, produced phenazine antibiotics in vitro (data not shown).

Suppression of Fusarium wilt of flax by $\mathrm{phzC}^{+}$and phl $D^{+}$pseudomonads

Earlier studies on the Châteaurenard Fusarium-wilt suppressive soil showed that disease suppressiveness was ascribed to the joint activity of nonpathogenic $F$. oxysporum and fluorescent pseudomonads (Lemanceau et al., 2006). Therefore, the efficacy of $p h z \mathrm{C}^{+}$and $p h / \mathrm{D}^{+}$isolates to control Fusarium wilt of flax was tested when inoculated separately (Figures 3a and c) and in combination with the non-pathogenic $F$. oxysporum strain Fo47
(Figures $3 \mathrm{~b}$ and d). The bacterial isolates (indicated with an asterisk in Figures 1 and 2) were chosen as representatives of the diversity of the indigenous populations: (i) an isolate of each of the five phzCRFLP genotypes from the Châteaurenard suppressive soil (genotypes I-IV) plus strain 2-79 (genotype VII), and (ii) two phlD ${ }^{+}$isolates of the phlD-RFLP dominant genotype $M$ from the Châteaurenard suppressive soil, one isolate of each of the dominant phID-RFLP genotypes $\gamma$ and $\delta$ from the conducive soil, and reference strain Phl60rif (genotype D).

The results show that none of the five $p h z \mathrm{C}^{+}$ strains was effective in disease control when applied alone (Figure 3a). However, when applied in combination with non-pathogenic $F$. oxysporum strain Fo47, they all improved the suppression a
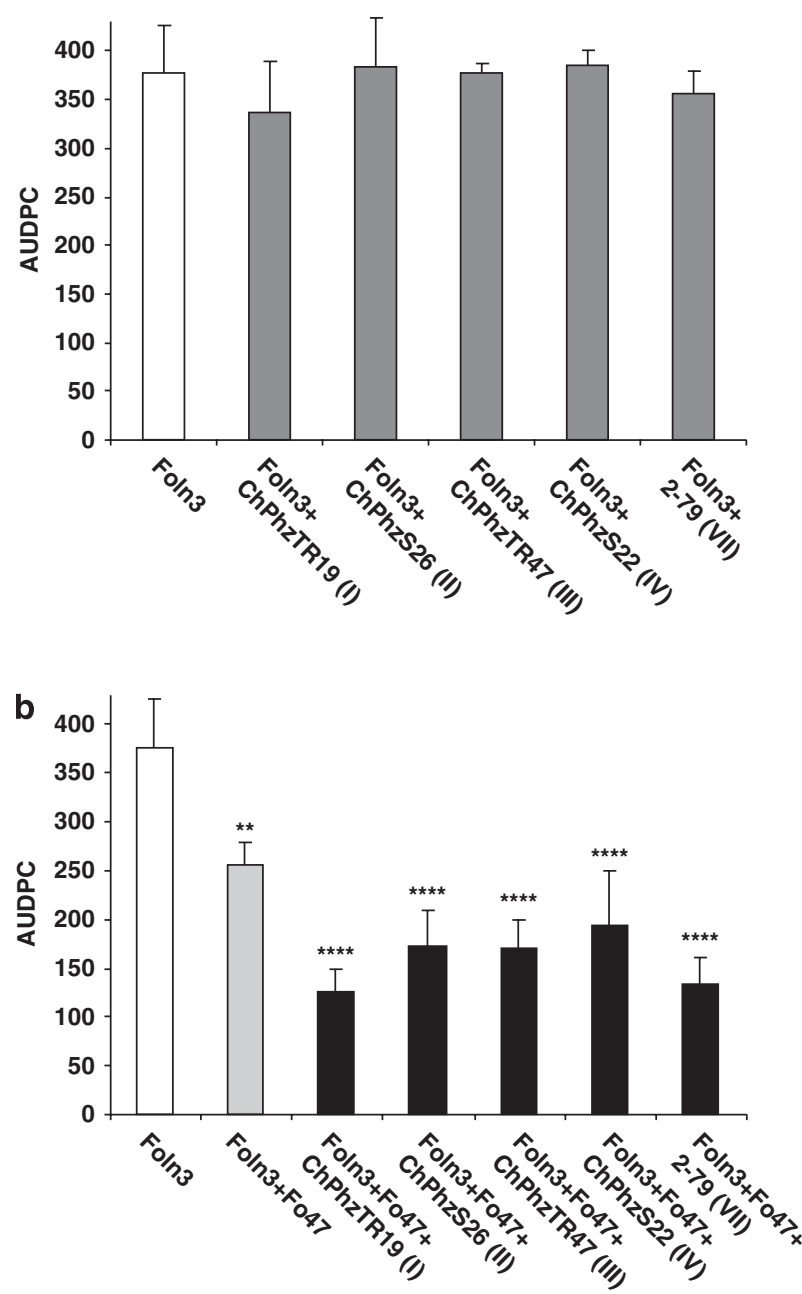

C

DAPG
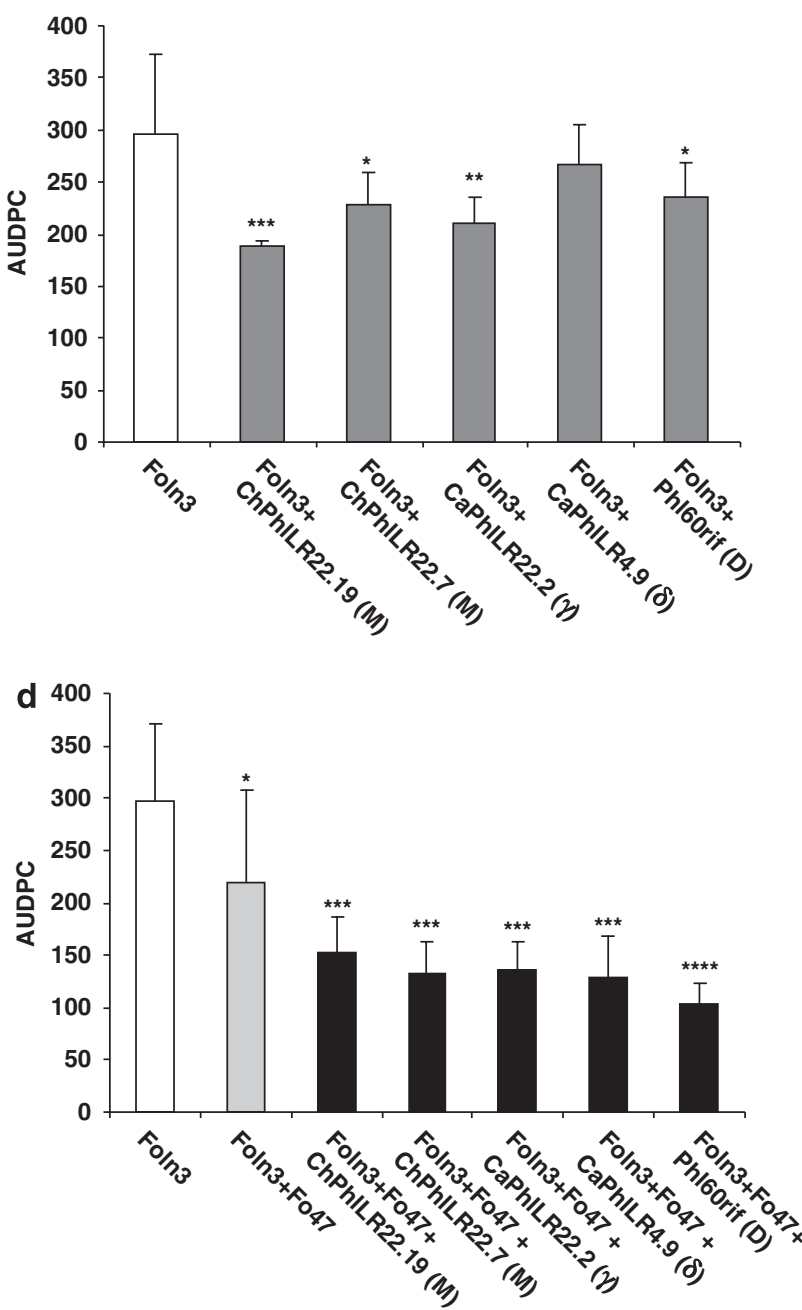

Figure 3 Protection of flax against Fusarium wilt by $p h z \mathrm{C}^{+}$Pseudomonas isolates obtained from the wilt-suppressive soil (a and b) and by phlD ${ }^{+}$Pseudomonas isolates obtained from the wilt-suppressive or conducive soil (c and d). For each of the Pseudomonas isolates tested, the corresponding genotypes as defined in Figures 1 and 2 are indicated between brackets. Plants were grown in soil infested with pathogenic F. oxysporum f.sp. lini Foln3 ( $10^{3}$ conidia $\mathrm{g}^{-1}$ soil fresh weight), and inoculated with cell suspensions of the Pseudomonas isolates $\left(10^{7} \mathrm{CFU} \mathrm{g}^{-1}\right.$ soil fresh weight) and non-pathogenic $F$. oxysporum Fo47 ( $10^{5}$ conidiag $^{-1}$ soil fresh weight) separately or in combination. The area under disease progress curve represents the cumulative disease severity monitored over a period of 6 weeks of plant growth. Error bars represent the s.d. of the mean. Fisher's PLSD-test was used for pair wise comparison of the treatment with the infested control (Foln 3 ): ${ }^{*} P \leqslant 0.1 ;{ }^{*} P \leqslant 0.05 ;{ }^{* * *} P \leqslant 0.01 ; * * * * P \leqslant 0.001$. 
achieved by Fo47 (Figure 3b). Regardless of their origins, four of the five phlD ${ }^{+}$strains significantly reduced Fusarium wilt of flax when applied alone (Figure 3c) and, when co-inoculated with Fo47, all enhanced the level of disease control (Figure 3d). To further resolve the role of DAPG and phenazine in disease control and in the synergy with nonpathogenic $F$. oxysporum strain Fo47, biosynthesis mutants deficient in DAPG (mutant 17-8D) or phenazine (mutant 2-79Z) production were tested and their biocontrol efficacy compared with their respective wild-type strains. The level of protection achieved by the two wild-type strains did not differ from that of their respective antibiotic-deficient mutants (Figures 4a and c). In the presence of Fo47, however, differential effects were observed between the DAPG and phenazine producers.
DAPG-producing strain Phl60rif and its DAPGdeficient mutant 17-8D both enhanced as efficiently the disease suppression by Fo47 (Figure 4d). In contrast, phenazine-producing strain 2-79 was more effective in combination with Fo47 than its phenazine-deficient mutant 2-79Z (Figure 4b). Collectively, these results suggest that phenazines, but not DAPG, contribute to the enhanced disease suppression achieved in combination with nonpathogenic $F$. oxysporum.

\section{Discussion}

To unravel the role of antibiosis in the natural soil suppressiveness to Fusarium wilt, this study used strategies that were earlier applied for take-all a
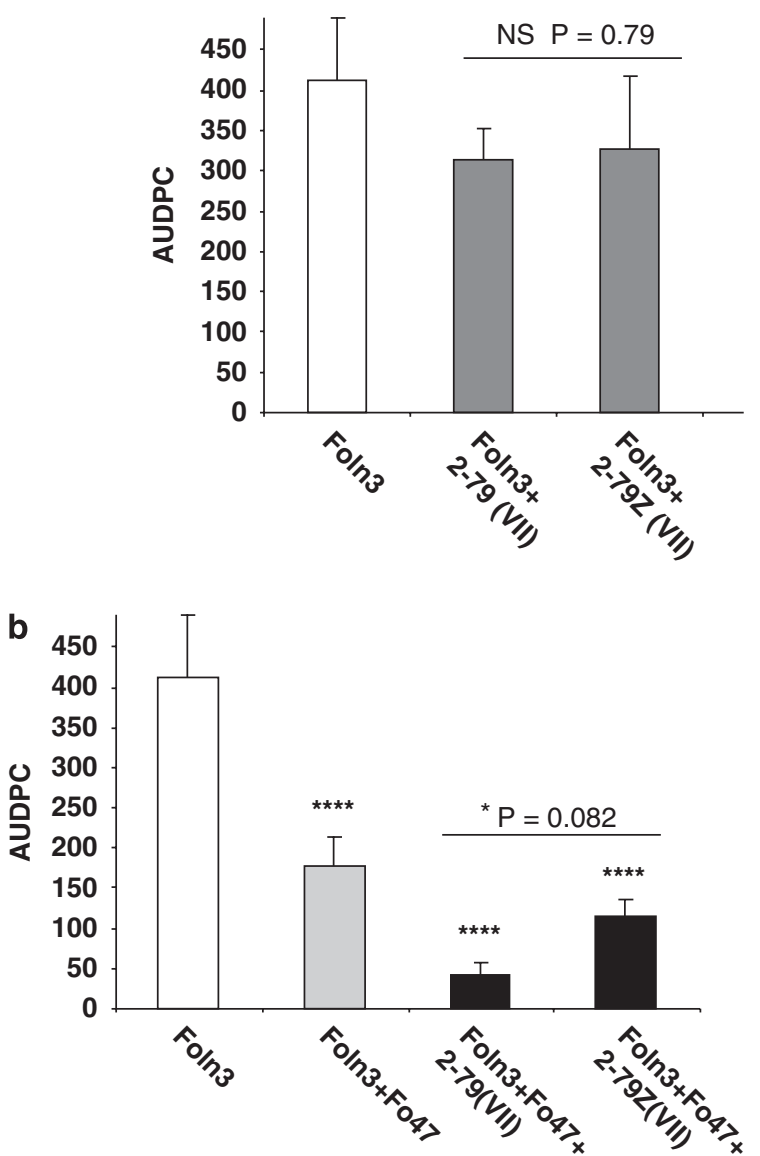

C
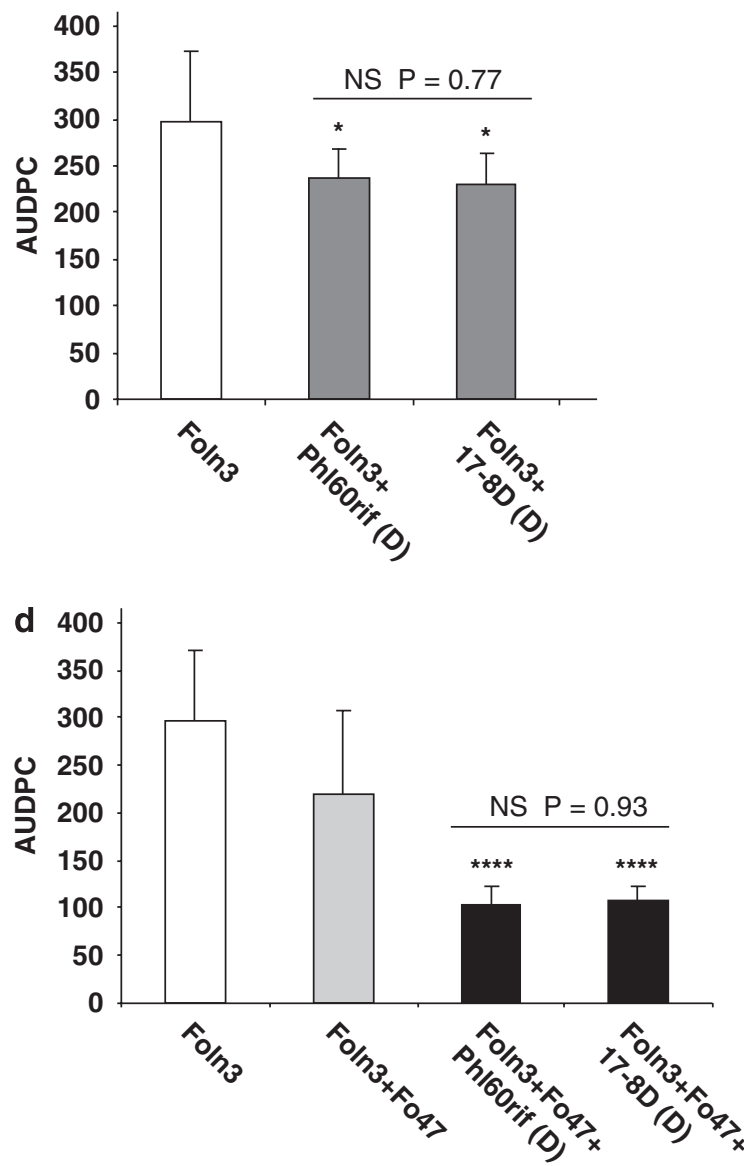

Figure 4 Protection of flax against Fusarium wilt by phenazine-producing strain P. fluorescens 2-79 and by 2,4-diacetylphloroglucinol (DAPG)-producing strain $P$. fluorescens Phl60rif. Each of the strains was tested alone or in combination with non-pathogenic F. oxysporum Fo47. For strain 2-79, the biocontrol efficacy was compared with that of its phenazine-deficient mutant 2-79Z (a and b); for strain Phl60rif, a comparison was made with its DAPG-deficient mutant 17-8D (c and d). Plants were grown in soil infested with pathogenic $F$. oxysporum f.sp. lini Foln3 $\left(10^{3}\right.$ conidiag $^{-1}$ soil fresh weight), and inoculated with cell suspensions of the Pseudomonas isolates $\left(10^{7} \mathrm{CFUg}^{-1}\right.$ soil fresh weight) and non-pathogenic $F$. oxysporum Fo47 $\left(10^{5}\right.$ conidiag $^{-1}$ soil fresh weight $)$ separately or in combination. The area under disease progress curve represents the cumulative disease severity monitored over a period of 6 weeks of plant growth. Error bars represent the s.d. of the mean. Fisher's PLSD-test was used for pair wise comparison of the treatment with the infested control (Foln 3 ): ${ }^{*} P \leqslant 0.1 ;{ }^{* * * *} P \leqslant 0.001$. The results of the statistical pair wise comparison between the effects of the wild-type strains and their antibiotic-deficient mutant are indicated with probability values. 
decline soils (Raaijmakers et al., 1997; Raaijmakers and Weller, 1998; McSpadden-Gardener et al., 2000; Weller et al., 2002; Souza et al., 2003a) and for soils suppressive to black root rot of tobacco (Wang et al., 2001; Ramette et al., 2003, 2006; Frapolli et al., 2007). This strategy encompasses a comparative analysis of the densities, diversity and activity of antibiotic-producing pseudomonads in two soils chosen for their opposite level of suppressiveness to Fusarium wilt: one being suppressive (Châteaurenard) and the other being conducive (Carquefou). These two soils were the same as those used earlier to show the role of carbon and iron competition in soil suppressiveness to Fusarium wilts (Lemanceau et al., 1988). At this stage, the two structurally different antibiotics DAPG and phenazines were considered because of their established role in the activity of various Pseudomonas strains against pathogenic $F$. oxysporum (Georgakopoulos et al., 1994; Anjaiah et al., 1998; Chin-A-Woeng et al., 1998; Schouten et al., 2004) and, for DAPG-producing pseudomonads, because of their prevalence in a soil naturally suppressive to Fusarium wilt of peas (Landa et al., 2002).

Molecular-based detection revealed that DAPGand phenazine-producing pseudomonads were present in the rhizosphere of flax and tomato plants grown in the wilt-suppressive soil. DAPG-producing pseudomonads were found at similar densities in the conducive soil, whereas phenazine-producing pseudomonads were only detected in the suppressive soil. To our knowledge, this is the first report establishing differences in population densities of phenazine-producing pseudomonads between disease suppressive and conducive soils. Furthermore, they also show the coexistence of DAPG- and phenazine-producing Pseudomonas in a naturally suppressive soil. Although phenazineproducing strain $P$. fluorescens 2-79 was originally isolated from a take-all suppressive soil and was shown to efficiently suppress take-all disease through the production of phenazine-1-carboxylic acid (Thomashow and Weller, 1988), the role of phenazine-producing Pseudomonas populations in the natural soil suppressiveness to take-all and other soil-borne diseases could not be confirmed (Raaijmakers et al., 1997; Mavrodi et al., 2006). The higher density of phenazine-producing Pseudomonas in the suppressive soil of Châteaurenard compared with the conducive soil of Carquefou may be related to differences in the physicochemical properties of these two soils. Indeed, owing to the high $\mathrm{pH}$ (7.9) and $\mathrm{CaCO}_{3}$ content of the Châteaurenard soil, the concentration of extractable iron was shown to be 15 times lower than that in the Carquefou soil (Lemanceau et al., 1988). As phenazines are redox-active antibiotics (Dietrich et al., 2008) and may contribute to iron mobilization in soils (Hernandez et al., 2004; Price-Whelan et al., 2006; Wang and Newman, 2008), the ability of bacteria to produce these metabolites may give them a competitive advantage under the iron-limiting conditions prevailing in the Châteaurenard suppressive soil.

At the genotypic level, the $p h z \mathrm{C}^{+}$isolates were distributed in five groups, four of them being closely related to reference strains known to produce different phenazine derivatives, including phenazine-1-carboxylic acid, 2-OH-phenazine-1-carboxylic acid and phenazine-1-carboxamide (reviewed by Mavrodi et al., 2006). The phlD genotypes found in the two soils differed substantially, with genotype $\mathrm{M}(81 \%$ of the isolates) being dominant in the suppressive soil. Interestingly, the two genotypes $\mathrm{M}$ and $\mathrm{F}$ identified in the suppressive soil of Châteaurenard were described earlier as being dominant in European take-all decline soils (Souza et al., 2003a). Phylogenetic analysis further revealed that the four phlD genotypes found in the conducive soil, designated $\alpha, \beta, \gamma$ and $\delta$, were not described so far (De La Fuente et al., 2006). Collectively, these results correspond well with the results obtained by Ramette et al. (2006) for the soils suppressive or conducive to black root rot of tobacco; in their work, DAPG-producing Pseudomonas spp. were also detected at similar densities in the conducive and suppressive soils and were genotypically diverse. However, in their study the different genotypes also differed in their biocontrol efficacy, whereas in this study the $p h / \mathrm{D}^{+}$isolates from the wilt-suppressive soil were equally effective as the isolates from the conducive soil. None of the genotypically different $p h \mathrm{zC}^{+}$isolates from the Fusarium-wilt suppressive soil were able to control Fusarium wilt of flax when inoculated separately; this includes isolate ChPhzS26 which belongs to the same phzC-RFLP genotype (II) as P. chlororaphis PCL1391, a strain that effectively suppressed crown and root rot of tomato caused by F. oxysporum f. sp. radicis lycopersici (Chin-AWoeng et al., 1998).

In contrast with suppressiveness to take-all, which has been ascribed mainly to fluorescent pseudomonads (Weller et al., 2002), soil suppressiveness to Fusarium wilt has been related to both non-pathogenic F. oxysporum (Rouxel et al., 1979) and fluorescent pseudomonads (Scher and Baker, 1980). Densities of indigenous populations of nonpathogenic $F$. oxysporum were shown earlier to be much higher in Fusarium wilt suppressive than in conducive soils (Alabouvette, 1986). Additional suppression by the combination of non-pathogenic F. oxysporum strain Fo47 and specific isolates of fluorescent pseudomonads was reported earlier (Lemanceau and Alabouvette, 1991; Lemanceau et al., 1992, Duijff et al., 1999) and proposed to account for the efficacy and stability of the natural suppressiveness (Lemanceau et al., 2006). Data shown here confirm that most of the isolates tested improved the protection achieved by Fo47. On the basis of the experiments with mutants affected in antibiotic biosynthesis, DAPG bio- 
synthesis does not seem to be involved in this increased protection. In contrast, this additional level of disease suppression was shown to be related to phenazine biosynthesis. Interestingly, the additional suppression provided by the bacterial and fungal combination was ascribed earlier to an interplay between carbon and iron competition achieved by these two groups of antagonistic microorganisms (Lemanceau et al., 1988, 1993): pyoverdine-mediated iron competition achieved by the fluorescent pseudomonads was shown to reduce the efficacy of carbon metabolism of the pathogenic F. oxysporum making it more susceptible to carbon competition with non-pathogenic $F$. oxysporum (Lemanceau et al., 1993). Considering that phenazines are redox-active antibiotics (Dietrich et al., 2008) and may contribute to iron mobilization in soils (Hernandez et al., 2004; Price-Whelan et al., 2006), they also could play a role in iron competition, thereby making pathogenic F. oxysporum more susceptible to carbon competition with non-pathogenic $F$. oxysporum. Alternatively, phenazines also could act against pathogenic $F$. oxysporum as redox-active antibiotics leading to the accumulation of toxic oxygen radicals (Mavrodi et al., 2006). Whether one or both modes of action of phenazines operate in Fusarium wilt suppressiveness remains to be explored.

One may consider that the colonization level of the indigenous $p h z \mathrm{C}^{+}$pseudomonads in the suppressive soil was lower than that of introduced phenazine-producing strains in the biocontrol experiments, and therefore may not be high enough for effective disease suppression. This complex issue highly depends on the spatial distribution of the bacteria and the level of expression of the antagonistic traits involved. Various studies performed so far show that the relationships between bacterial densities on plant roots and the level of disease control are nonlinear and have an asymptotic nature (Bull et al., 1991; Johnson, 1994; Raaijmakers et al., 1995; Raaijmakers and Weller, 1998). These studies further show that when indigenous or introduced Pseudomonas populations reach a density in the rhizosphere of $10^{3}$ $10^{5} \mathrm{CFUg}^{-1}$ of root fresh weight, several fungal diseases, including Fusarium wilt, are controlled to some degree. At densities above $10^{5} \mathrm{CFUg}^{-1}$ of root, there is no further improvement in the level of disease control (Raaijmakers et al., 1995; Raaijmakers and Weller, 1998), which is probably related to the spatial heterogeneity of the

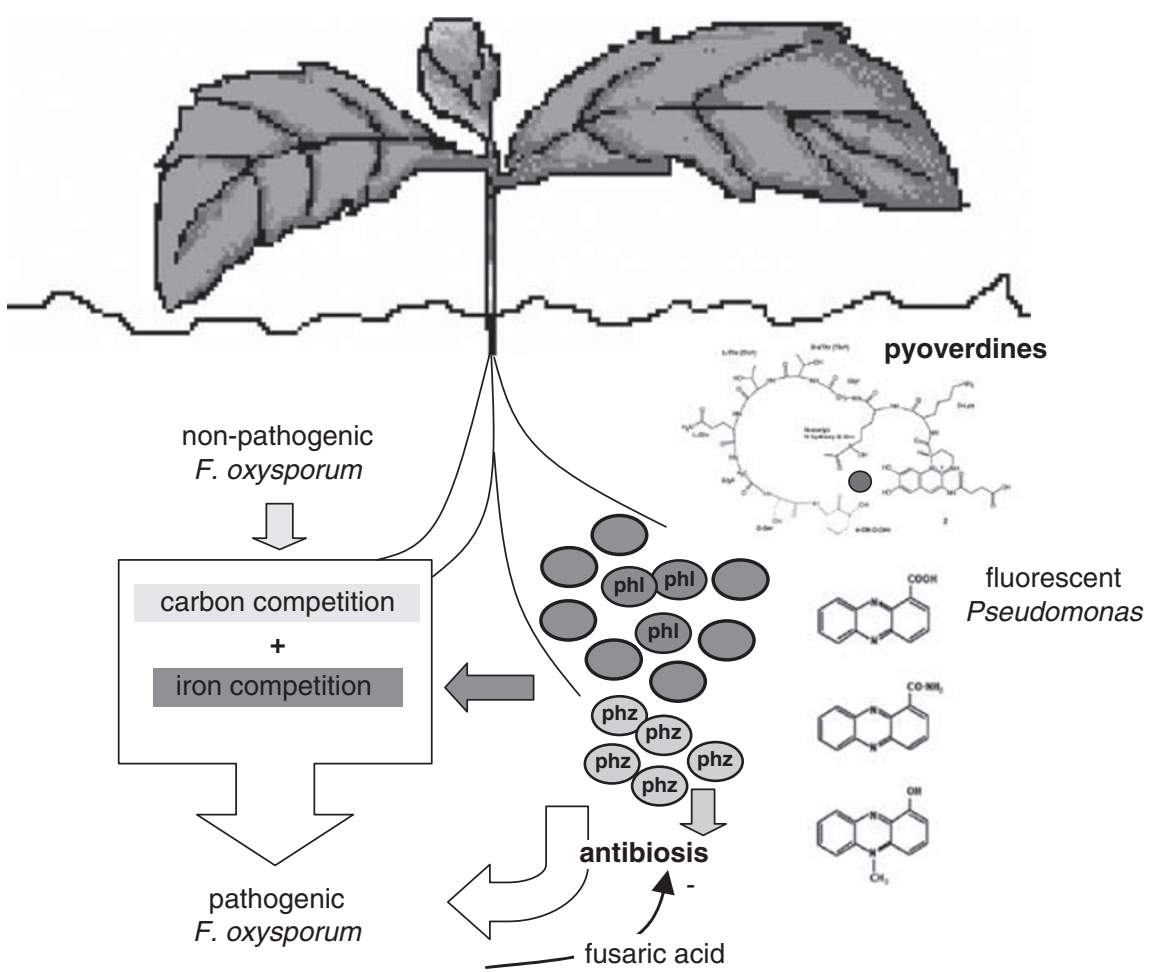

Figure 5 Schematic model presenting the proposed mechanisms that contribute to the natural soil suppressiveness to Fusarium wilt. The significant higher microbial biomass in the suppressive soil as compared with the conducive soil contributes to a higher level of carbon competition in the suppressive soil. On this background of general competition, the higher density of non-pathogenic F. oxysporum in the suppressive soil further increases the carbon competition. The suppressive soil also differs from the conducive soil by its lower concentration of extractable iron, due to its high $\mathrm{pH}$ and $\mathrm{CaCO}_{3}$ content, making pyoverdine-mediated iron competition between the pathogen and the fluorescent pseudomonads stronger in the suppressive than in the conducive soil. Carbon and iron competition act in synergy to suppress the saprophytic growth of pathogenic $F$. oxysporum, leading to a reduced activity and rate of root infection. The results of this study suggest that also redox-active phenazine antibiotics may play a role in Fusarium wilt suppressiveness and may act in synergy with the carbon competition achieved by non-pathogenic $F$. oxysporum. In return, fusaric acid produced by $F$. oxysporum may affect the activity of the fluorescent pseudomonads by interference with the expression of antibiotic biosynthesis genes. 
indigenous/introduced bacteria and the level of colocalization of the bacteria and the pathogen. These quantitative dose-response relationships were shown for several Pseudomonas strains and mechanisms, including phenazine-mediated antibiosis by strain 2-79 (Bull et al., 1991), DAPGmediated antibiosis (Raaijmakers and Weller, 1998), siderophore-mediated competition for iron and induced systemic resistance (Raaijmakers et al., 1995). Therefore, the population densities of the indigenous $p h z \mathrm{C}^{+}$pseudomonads reported in our study do reach population densities within the range, where at least some level of disease control can be expected. This is certainly the case for $\mathrm{phzC}^{+}$Pseudomonas populations in the tomato rhizosphere but to a lesser extent for flax. However, when acting in synergy with other antagonistic microorganisms and mechanisms, these relatively low population densities may contribute to disease control (Olivain et al., 2004).

The observation that DAPG production did not play a significant role in the enhanced disease suppression achieved by strain Phl60rif in combination with Fo47 may have been due to various factors. One important factor in this respect is the choice of the phlD genotype tested, which may substantially affect the level of disease control (Raaijmakers and Weller, 2001; Ramette et al., 2006). Therefore, more phlD genotypes and their respective DAPG-deficient mutants need to be tested to more conclusively assess the contribution of the antibiotic DAPG in the natural soil suppressiveness to Fusarium wilt disease. Furthermore, DAPG biosynthesis may also have been repressed by specific environmental conditions (Duffy and Défago, 1999) or by fusaric acid (Figure 5; Notz et al., 2002; Duffy et al., 2004), a phytotoxin produced by pathogenic $F$. oxysporum and non-pathogenic $F$. oxysporum strain Fo47 (Schouten et al., 2004). However, given that also phenazine production can be repressed by fusaric acid (Van Rij et al., 2004, 2005), it seems unlikely that this phytotoxin played a major role in the multitrophic interactions occurring in the biocontrol assays.

In conclusion, the data presented in this study provide, for the first time, evidence that phenazineproducing pseudomonads are enriched in the Fusarium-wilt suppressive soil of Châteaurenard, and when combined with non-pathogenic F. oxysporum, significantly enhance disease suppressiveness either directly through antibiosis and/ or indirectly through iron competition (Figure 5). The suppressive soil of Châteaurenard shows a high $\mathrm{pH}$ and $\mathrm{CaCO}_{3}$ content, and hosts an abundant microflora. These microbial characteristics lead to strong competition for carbon, whereas the physico-chemical characteristics of the Châteaurenard soil contribute to a strong competition for the poorly available iron. Non-pathogenic $F$. oxysporum, which are much more abundant in the suppressive than in the conducive soil, successfully compete for carbon sources with pathogenic $F$. oxysporum with which they share similar trophic requirements. At the same time, fluorescent pseudomonads decrease the iron availability for pathogenic $F$. oxysporum, which are more susceptible to iron starvation than non-pathogenic $F$. oxysporum (Figure 5). We postulate that redox-active phenazine antibiotics play a role in the control of pathogenic $F$. oxysporum by indigenous fluorescent pseudomonads, and when acting in synergy with carbon and iron competition contribute to the longstanding nature of the soil suppressiveness to Fusarium wilt disease.

\section{Acknowledgements}

This study was funded by OECD, the Regional Council of Burgundy (Dijon, France), the Royal Dutch Academy of Arts and Sciences (KNAW) and NWO-Van Gogh (project VGP 83-192). We are grateful to DV Mavrodi and LS Thomahsow (USDA-ARS, Washington State University, Pullman, WA, USA) for kindly providing the phenazinedeficient mutant 2-79Z. We also acknowledge the Experimental Unit of INRA (SEDE, Dijon, France) for biocontrol assay facilities.

\section{References}

Alabouvette C. (1986). Fusarium-wilt suppressive soils from the Châteaurenard region: review of a 10-year study. Agronomie 6: 273-284.

Alabouvette C. (1990). Biological control of Fusarium wilt pathogens in suppressive soils. In: Hornby D (ed). Biological Control of Soil-Borne Plant Pathogens. CAB International, Wallingford, England. pp 27-43.

Amir H, Amir A. (1989). Influence de la désinfection et du type de sol sur l'antagonisme d'un actinomycete vis-àvis d'une souche de Fusarium oxysporum f sp. albedinis. Rev Ecol Biol Sol 26: 57-74.

Anjaiah V, Koedam N, Nowak-Thompson B, Loper JE, Höfte M, Tambong JT et al. (1998). Involvement of phenazines and anthranilate in the antagonism of Pseudomonas aeruginosa PNA1 and Tn5-derivatives towards Fusarium sp. and Pythium sp. Mol PlantMicrobe Interact 11: 847-854.

Bergsma-Vlami M, Prins ME, Staatzs M, Raaijmakers JM. (2005). Assessment of genotypic diversity of antibiotic producing Pseudomonas species in the rhizosphere by denaturing gradient gel electrophoresis. Appl Environ Microbiol 71: 993-1003.

Bull CT, Weller DM, Thomashow LS. (1991). Relationship between root colonization and suppression of Gaeumannomyces graminis var. tritici by Pseudomonas fluorescens strain 2-79. Phytopathology 81: 954-959.

Chin-A-Woeng TFC, Bloemberg GV, Van der Bij AJ, Van der Drift KMGM, Schripsema J, Kroon B et al. (1998). Biocontrol by phenazine-1-carboxamide producing Pseudomonas chlororaphis PCL1391 of tomato root rot caused by Fusarium oxysporum f. sp. radicislycopersici. Mol Plant-Microbe Interact 10: 79-86. 
Chin-a-Woeng TFC, Bloemberg GV, Mulders IHM, Dekkers LC, Lugtenberg BJJ. (2000). Root colonization by phenazine-1-carboxamide-producing bacterium Pseudomonas chlororaphis PCL1391 is essential for biocontrol of tomato foot and root rot. Mol PlantMicrobe Interact 13: 1340-1345.

Cook RJ, Thomashow LS, Weller DM, Fujimoto D, Mazzola $\mathrm{M}$, Bangera $\mathrm{G}$ et al. (1995). Molecular mechanisms of defense by rhizobacteria against root disease. Proc Natl Acad Sci USA 92: 4197-4201.

De La Fuente L, Mavrodi DV, Landa BB, Thomashow LS, Weller DM. (2006). phID-based genetic diversity and detection of genotypes of 2,4-diacetylphloroglucinolproducing Pseudomonas fluorescens. FEMS Microbiol Ecol 56: 64-78.

Dietrich LEP, Teal TK, Price-Whealan A, Newman DK. (2008). Redox-active antibiotics control gene expression and community behavior of divergent bacteria. Science 321: 1203-1206.

Duijff BJ, Recorbet G, Bakker PAHM, Loper J, Lemanceau P. (1999). Microbial antagonism at the root level is involved in the suppression of Fusarium wilt by the combination of non-pathogenic Fusarium oxysporum Fo47 and Pseudomonas putida WCS358. Phytopathology 89: 1073-1079.

Duffy BK, Défago G. (1999). Environmental factors modulating antibiotic and siderophore biosynthesis by Pseudomonas fluorescens biocontrol strains. Appl Environ Microbiol 65: 2429-2438.

Duffy BK, Keel C, Défago G. (2004). Potential role of pathogen signalling in multitrophic plant-microbe interactions involved in disease protection. Appl Environ Microbiol 70: 1836-1842.

Frapolli M, Défago G, Moënne-Loccoz Y. (2007). Multilocus sequence analysis of biocontrol fluorescent Pseudomonas spp. producing the antifungal compound 2,4-diacetylphloroglucinol. Environ Microbiol 9: 1939-1955.

Georgakopoulos D, Hendson M, Panopoulos NJ, Schroth MN. (1994). Cloning of a phenazine biosynthetic locus of Pseudomonas aureofaciens PGS12 and analysis of its expression in vitro with the ice nucleation reporter gene. Appl Environ Microbiol 60: 2931-2938.

Hernandez ME, Kappler A, Newman DK. (2004). Phenazines and other redox-active antibiotic promote microbial mineral reduction. Appl Environ Microbiol 70: 921-928.

Holloway BW. (1955). Genetic recombination in Pseudomonas aeruginosa. J Gen Microbiol 13: 572-581.

Hornby D. (1979). Take-all decline: a theorist's paradise. In: Schippers B, Gams W (eds). Soil-Borne Plant Pathogens. Academic Press: London. pp 133-156.

Howell CR, Stipanovic RD. (1979). Control of Rhizoctonia solani on cotton seedlings with Pseudomonas fluorescens and with an antibiotic produced by the bacterium. Phytopathology 69: 480-482.

Jaccard P. (1908). Nouvelles recherches sur la distribution florale. Bull Soc Vaud Sci Nat 44: 223-270.

Johnson KB. (1994). Dose-response relationships and inundative biological control. Phytopathology 84: 780-784.

Khan SR, Mavrodi DV, Jog GJ, Suga H, Thomashow LS, Farrand SK. (2005). Activation of the phz operon of Pseudomonas fluorescens 2-79 requires the LuxR homolog PhzR, N-(3-OH-hexanoyl)-L-homoserine lactone produced by the LuxI homologue PhzI, and a cisacting phz-box. J Bacteriol 187: 6517-6527.
Kimura M. (1980). A simple method for estimating evolutionary rate of base substitution through comparative studies of nucleotide sequences. J Mol Evol 16: $111-120$.

King EO, Ward MK, Raney DE. (1954). Two simple media for demonstration of pyocyanin and fluorescein. J Lab Clin Med 44: 301-307.

Kloepper JW, Leong J, Teintze M, Schroth MN. (1980). Pseudomonas siderophores: a mechanism explaining disease-suppressive soils. Curr Microbiol 4: 327-330.

Landa BB, Mavrodi OV, Raaijmakers JM, McSpaddenGardener BB, Thomashow LS, Weller DM. (2002). Differential ability of genotypes of 2,4-diacetylphloroglucinol-producing Pseudomonas fluorescens to colonize the roots of pea. Appl Environ Microbiol 68: 3226-3237.

Landa BB, Mavrodi OV, Schroeder KL, Allende-Mola R, Weller DM. (2006). Enrichment and genotypic diversity of phlD-containing fluorescent Pseudomonas spp. in two soils after a century of wheat and flax monoculture. FEMS Microbiol Ecol 55: 351-368.

Larkin RP, Hopkins DL, Martin FN. (1996). Suppression of Fusarium wilt of watermelon by non-pathogenic Fusarium oxysporum and other microorganisms recovered from disease suppressive soil. Phytopathology 86: 812-819.

Latour X, Corberand T, Laguerre G, Allard F, Lemanceau P. (1996). The composition of fluorescent pseudomonad populations associated with roots is influenced by plant and soil type. Appl Environ Microbiol 62: 2449-2456.

Lemanceau P, Alabouvette C. (1991). Biological control of Fusarium diseases by fluorescent Pseudomonas and non-pathogenic Fusarium. Crop Protect 10: 279-286.

Lemanceau P, Alabouvette C. (1993). Suppression of Fusarium wilts by fluorescent pseudomonads: mechanisms and applications. Biocontrol Sci Technol 3: 219-234.

Lemanceau P, Alabouvette C, Couteaudier Y. (1988). Recherches sur la résistance des sols aux maladies. XIV. Modification du niveau de réceptivité d'un sol résistant et d'un sol sensible aux fusarioses vasculaires en réponse à des apports de fer ou de glucose. Agronomie 8: 155-162.

Lemanceau P, Bakker PAHM, De Kogel WJ, Alabouvette C, Schippers B. (1992). Effect of pseudobactin 358 production by Pseudomonas putida WCS358 on suppression of Fusarium wilt of carnations by nonpathogenic Fusarium oxysporum Fo47. Appl Environ Microbiol 58: 2978-2982.

Lemanceau P, Bakker PAHM, De Kogel WJ, Alabouvette C, Schippers B. (1993). Antagonistic effect of nonpathogenic Fusarium oxysporum Fo47 and pseudobactin 358 upon pathogenic Fusarium oxysporum f. sp. dianthi. Appl Environ Microbiol 59: 74-82.

Lemanceau P, Maurhofer M, Défago G. (2006). Contribution of studies on suppressive soils to the identification of bacterial biocontrol agents and to the knowledge of their modes of action. In: Gnanamanickam SS (ed). Plant-Associated Bacteria. Springer: Dordrecht. pp 231-267.

Mavrodi DV, Blankenfeldt W, Thomashow LS. (2006). Phenazine compounds in fluorescent Pseudomonas spp. biosynthesis and regulation. Annu Rev Phytopathol 44: 417-445. 
Mavrodi OV, McSpadden-Gardener BB, Mavrodi DV, Bonsall RF, Weller DM, Thomashow LS. (2001). Genetic diversity of phlD from 2,4-diacetylphloroglucinol-producing fluorescent Pseudomonas species. Phytopathology 91: 35-43.

McSpadden-Gardener BB, Mavrodi DV, Thomashow LS, Weller DM. (2001). A rapid polymerase chain reactionbased assay characterizing rhizosphere populations of 2,4-diacetylphloroglucinol-producing bacteria. Phytopathology 91: 44-54.

McSpadden-Gardener BB, Schroeder KL, Kalloger SE, Raaijmakers JM, Thomashow LS, Weller DM. (2000). Genotypic and phenotypic diversity of phlD-containing Pseudomonas isolated from the rhizosphere of wheat. Appl Environ Microbiol 66: 1939-1946.

Notz R, Maurhofer M, Dubach H, Haas D, Defago G. (2002). Fusaric acid-producing strains of Fusarium oxysporum alter 2,4-diacetylphloroglucinol biosynthetic gene expression in Pseudomonas fluorescens CHA0 in vitro and in the rhizosphere of wheat. Appl Environm Microbiol 68: 2229-2235.

Olivain C, Alabouvette C, Steinberg C. (2004). Production of a mixed inoculums of Fusarium oxysporum Fo47 and Pseudomonas fluorescens C7 to control Fusarium diseases. Bio Sci Technol 14: 227-238.

Pierson LS, Thomashow LS. (1992). Cloning and heterologous expression of the phenazine biosynthetic locus from Pseudomonas aureofaciens 30-84. Mol PlantMicrobe Interact 5: 330-339.

Price-Whelan A, Dietrich LE, Newman DK. (2006). Rethinking 'secondary' metabolism: physiological roles for phenazine antibiotics. Nat Chem Biol 2: 71-78.

Raaijmakers JM, Leeman M, van Oorschot MMP, van der Sluis I, Schippers B, Bakker PAHM. (1995). Doseresponse relationships in biological control of Fusarium wilt of radish by Pseudomonas spp. Phytopathology 85: 1075-1081.

Raaijmakers JM, Weller DM. (1998). Natural plant protection by 2,4-diacetylphloroglucinol-producing Pseudomonas spp. in take-all decline soils. Mol PlantMicrobe Interact 11: 144-152.

Raaijmakers JM, Weller DM. (2001). Exploiting genotypic diversity of 2,4-diacetylphloroglucinol producing Pseudomonas spp.: characterization of superior rootcolonizing P. fluorescens strain Q8r1-96. Appl Environ Microbiol 67: 2545-2554.

Raaijmakers JM, Weller DM, Tomashow LS. (1997). Frequency of antibiotic-producing Pseudomonas sp. in natural environments. Appl Environ Microbiol 63: 881-887.

Rademaker JLW, Louws FJ, De Bruijn FJ. (1997). Characterization of the diversity of ecologically important microbes by rep-PCR genomic fingerprinting. In: Akkermans ADL, Van Elsas D, De Bruijn JD (eds). Supplement 3, chapter 3.4.3 Molecular Microbial Ecology Manual. Kluwer Academic Publishers: Dordrecht. pp 1-26.

Ramette A, Moënne-Loccoz Y, Défago G. (2003). Prevalence of fluorescent pseudomonads producing antifungal phloroglucinols and/or hydrogen cyanide in soils naturally suppressive or conducive to tobacco black rot. FEMS Microbiol Ecol 44: 35-43.

Ramette A, Moënne-Loccoz Y, Défago G. (2006). Genetic diversity and biocontrol potential of fluorescent pseudomonads producing phloroglucinols and HCN from Swiss soils naturally suppressive or conducive to
Thielaviopsis basicola-mediated black root rot of tobacco. FEMS Microbiol Ecol 55: 369-381.

Rouxel F, Alabouvette C, Louvet J. (1979). Recherches sur la résistance des sols aux maladies. IV. Mise en évidence du rôle des Fusarium autochtones dans la résistance d'un sol à la Fusariose vasculaire du Melon. Ann Phytopathol 2: 199-207.

Saitou N, Nei M. (1987). The neighbor-joining method: a new method for reconstructing phylogenetic trees. Mol Biol Evol 4: 406-425.

Scher FM, Baker R. (1980). Mechanism of biological control in a Fusarium-suppressive soil. Phytopathology 70: 412-417.

Scher FM, Baker R. (1982). Effect of Pseudomonas putida and a synthetic iron chelator on induction of suppressiveness to Fusarium-wilt pathogens. Phytopathology 72: 1567-1573.

Schouten A, van den Berg G, Edel-Hermann V, Steinberg C, Gautheron N, Alabouvette C et al. (2004). Defense responses of Fusarium oxysporum to 2,4-diacetylphloroglucinol, a broad-spectrum antibiotic produced by Pseudomonas fluorescens. Mol Plant-Microbe Interact 17: 1201-1211.

Shanahan P, O’Sullivan DJ, Simpson P, Glennon JD, O'Gara F. (1992). Isolation of 2,4-diacetylphloroglucinol from a fluorescent pseudomonad and investigation of physiological parameters influencing its production. Appl Environ Microbiol 58: 353-358.

Simon A, Ridge EH. (1974). The use of ampicillin in a simplified selective medium for the isolation of fluorescent pseudomonads. J Appl Bacteriol 37: 459-460.

Sivan A, Chet I. (1989). The possible role of competition between Trichoderma harzianum and Fusarium oxysporum on rhizosphere colonization. Phytopathology 79: 198-203.

Souza JT, Weller DM, Raaijmakers JM. (2003a). Frequency, diversity, and activity of 2,4-diacetylphloroglucinolproducing fluorescent Pseudomonas spp. in Dutch take-all decline soils. Phytopathology 93: 54-63.

Souza JT, Arnould C, Deulvot C, Lemanceau P, GianinazziPearson V, Raaijmakers JM. (2003b). Effect of 2,4diacetylphloroglucinol on Pythium species: cellular responses and variation in sensitivity among propagules and species. Phytopathology 93: 966-975.

Steinberg C, Edel-Hermann V, Guillemaut C, PérezPiqueres A, Singh P, Alabouvette C. (2004). Impact of organic amendments on soil suppressiveness to diseases. In: Sikora RA, Gowen S, Hauschild R, Kiewnick S (eds). Multitrophic Interactions in Soil and Integrated Control, 1-4 June 2003: IOBC wprs Bulletin/Bulletin OILB srop Bonn, Germany. pp 259-266.

Steinberg C, Edel-Hermann V, Alabouvette C, Lemanceau P. (2007). Soil suppressiveness to plant diseases. In: Van Elsas D, Jansson JK, Trevors JT (eds). Modern Soil Microbiology, 2nd edn. CRC Press, Taylor \& Francis Group: London. pp 455-477.

Stutz EW, Défago G, Kern H. (1986). Naturally occurring fluorescent pseudomonads involved in suppression of black root rot of tobacco. Phytopathology 76: 181-185.

Thomashow LS, Weller DM. (1988). Role of a phenazine antibiotic from Pseudomonas fluorescens in biological control of Gaeumannomyces graminis var. tritici. J Bacteriol 170: 3499-3508.

Thompson JD, Higgins DG, Gibson TJ. (1994). CLUSTALW: improving the sensitivity of progressive multiple 
sequence alignment through sequence weighting, positions-specific gap penalties and weight matrix choice. Nucleic Acids Res 22: 4673-4680.

Van Rij ET, Wesselink M, Chin-A-Woeng TFC, Bloemberg GV, Lugtenberg BJJ. (2004). Influence of environmental conditions on the production of phenazine-1-carboxamide by Pseudomonas chlororaphis PCL1391. Mol Plant-Microbe Interact 17: 557-566.

Van Rij ET, Girard G, Lugtenberg BJJ, Bloemberg GV. (2005). Influence of fusaric acid on phenazine-1carboxamide synthesis and gene expression of Pseudomonas chlororaphis strain PCL1391. Microbiology 151: 2805-2814.

Vincent MN, Harrison LA, Brackin JM, Kovacevich PA, Mukerji P, Weller DM et al. (1991). Genetic analysis of the antifungal activity of a soilborne Pseudomonas aureofaciens strain. Appl Environ Microbiol 57: 2928-2934.

Wang Y, Newman DK. (2008). Redox reactions of phenazine antibiotics with ferric (hydr)oxides and molecular oxygen. Environ Sci Technol 42 2380-2386.

Wang C, Ramette A, Punjasamarnwong P, Zala M, Natsch A, Moenne-Loccoz Y et al. (2001). Cosmopolitan distribution of phlD-containing dicotyledonous cropassociated biocontrol pseudomonads of worldwide origin. FEMS Microbiol Ecol 37: 105-116.

Weller DM, Cook RJ. (1983). Suppression of take-all of wheat by seed treatment with fluorescent pseudomonads. Phytopathology 73: 463-469.

Weller DM, Raaijmakers JM, McSpadden Gardener BB, Thomashow LS. (2002). Microbial populations responsible for specific soil suppressiveness to plant pathogens. Annu Rev Phytopathol 40: 309-348.

Yuen GY, Schroth MN. (1986). Interactions of Pseudomonas fluorescens strain E6 with ornamental plants and its effect on the composition of root-colonizing microflora. Phytopathology 76: 176-180.

Supplementary Information accompanies the paper on The ISME Journal website (http://www.nature.com/ismej) 